
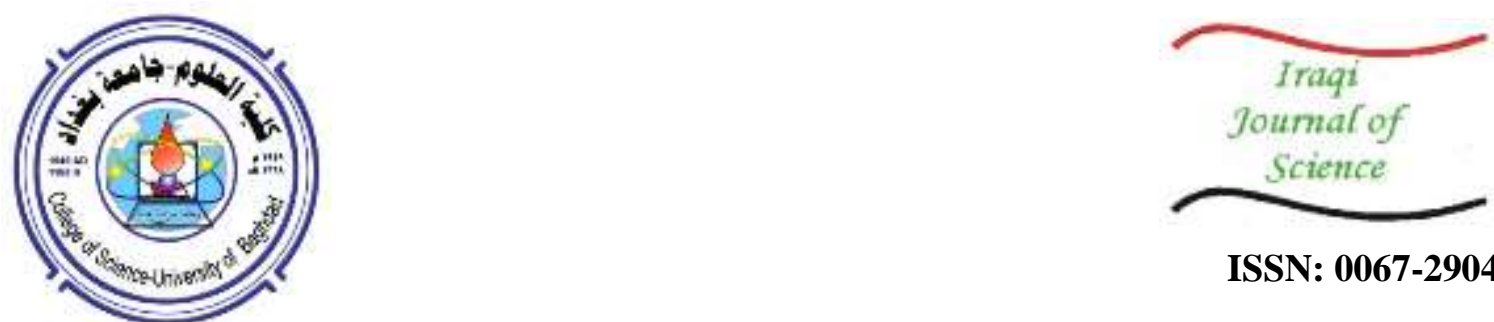

ISSN: 0067-2904

\title{
Assessment of the Toxic Elements Resulting from the Manufacture of Bricks on Air and Soil at Abu Smeache Area - Southwest Babylon governorate - Iraq
}

\author{
Murtadha J. Issa ${ }^{1}$, Hussain Musa Hussain ${ }^{2}$, Inas hadi Shaker*1 \\ ${ }^{1}$ Department of Geology, College of Science, University of Baghdad, Baghdad, Iraq \\ ${ }^{2}$ Department of Geology, College of Science, University of Kufa, AL-Najaf, Iraq
}

Received: 8/5/2019 Accepted: 17/7/2019

\begin{abstract}
Brick factories distributed within the study area use fuel oil to complete the burning of the bricks, were high amounts of gases and suspended particles with different concentrations of heavy elements are produced and cause air and soil pollution. It is noted that the workers suffer from respiratory diseases and other health problems. This study is an attempt to detect the sources and concentrations of pollutants and to propose modalities for their treatment and reduction. Air and soil samples were collected from different sites in Abu Smeache brick factory in Al-Kifl area to the south of Babel city, Iraq, during two seasons (summer and winter). The process also included collecting and modelling of dust and soil samples from two depth, surface and sub-surface, to detect pollution and the mobility of heavy elements across the different depths. Heavy elements $(\mathrm{Pb}, \mathrm{Ni}, \mathrm{Co})$, along with gases $(\mathrm{CO}, \mathrm{CO} 2, \mathrm{NO} 2, \mathrm{SO} 2)$ and total suspended particles (TSP) in the air, were analyzed by atomic absorption spectroscopy. The air results showed high pollution with all the studied heavy elements, while the levels of TSP and SO2 were higher than global and Iraqi limits in most of the studied stations, especially in the winter. The results also showed significant pollution in the soil with lead along with slight contamination with nickel and cobalt. Soil contamination was evaluated using several contamination indices; the values of contamination factors (CF) for the lead were very high, while CF values for nickel and copper indicated low to moderate pollution. Also, the high values of PLI $>1$ in the soil indicated high pollution with heavy elements, which provides clear evidence of the impact of industrial human activities on the environment of the region. In addition, low values of i-geo indicated a moderate contamination with lead and an unpolluted status for both nickel and copper. These results indicate a great need to develop strategies to prevent and reduce pollution by heavy metals in the areas under rapid industrial and urban development.
\end{abstract}

Keywords: Heavy elements, TSP, contamination factors, Brick factory,Al- Kifl Babylon.



*Email:enashadi88@gmail.com 


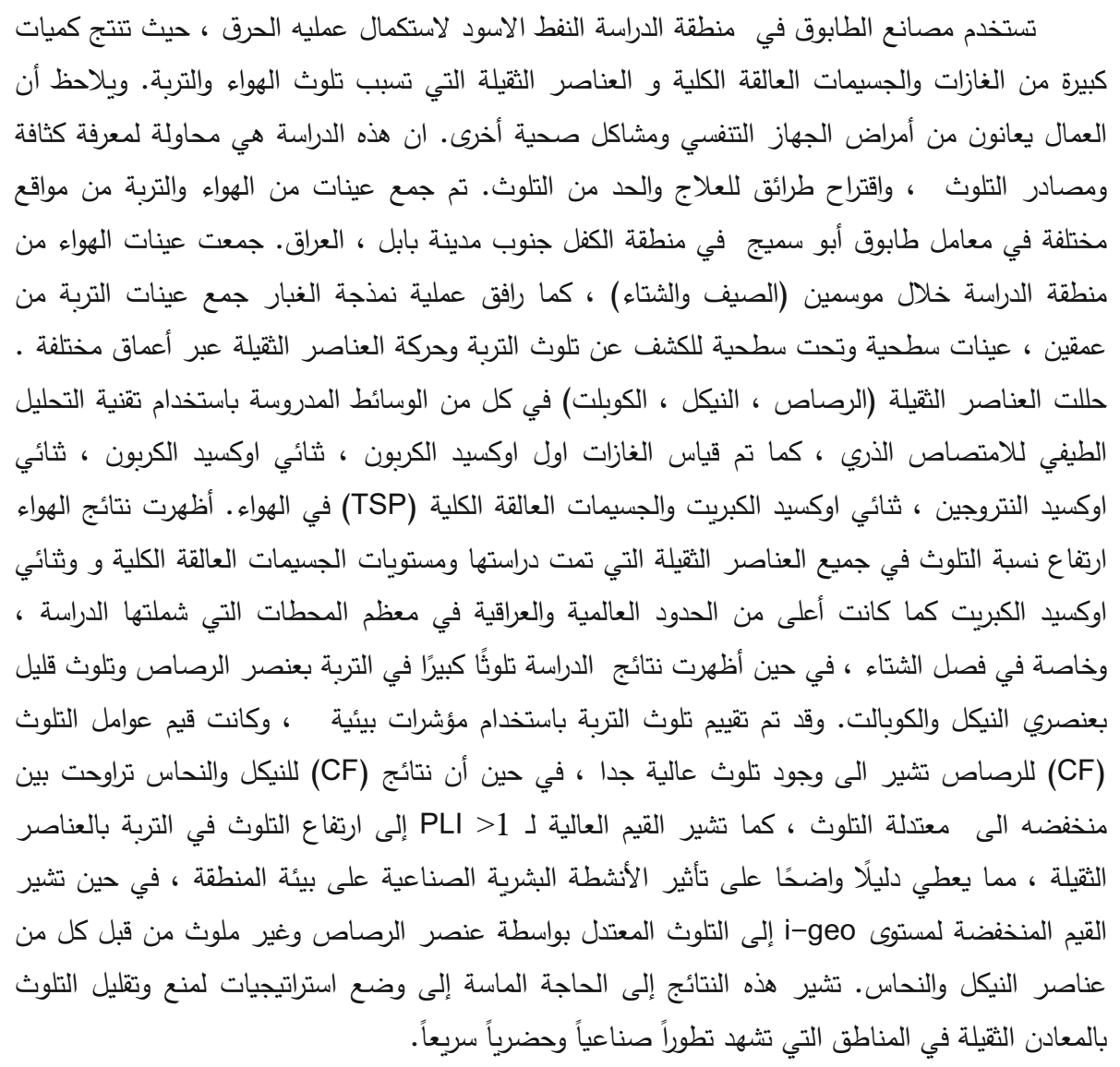

\section{1- Introduction}

Traditional industries, such as brick factories, have an adverse effect on the environment because of the pollution caused by gases emission, evaporation, dust as well as solid materials and hydrocarbons that goes through sewage outlets to the rivers adjacent to industrial projects. The brick industry is one of the oldest traditional industries that showed only slight advances in the development of means of production. These industries have an environmental impact on the areas in which these brick factories are located. They continue to produce solid, liquid and gaseous wastes [1]

In Babylon Governorate (province of Al- Kifl) many of the brick factories have potential negative impact on the environmental situation of the area, especially that the area is located close to the residential neighbourhoods. Crude oil is used as fuel in the kiln of the brick industry, which is an essential cause of pollution with gaseous waste, one of the most dangerous wastes made of the residues of gases, dust and volatile atoms, containing heavy elements that have toxic effects on the human, animals and plants. These factories can be more harmful than other technical factories as they have a low-rise coefficient that does not exceed the height of $3 \mathrm{~m}$, which leads to soil pollution in the factories and the areas surrounding themSoil is considered one of the crucial components in any environment, whether rural or urban, and is subjected to pollutants coming from different anthropogenic sources, including combustion of fuels in brick kilns and solid wastes. The heavy elements and gases emitted, such as $\mathrm{SO}_{2} . \mathrm{NO}_{2}, \mathrm{CO}_{2}$ and $\mathrm{CO}$, are one of the results of these polluted sources. Previous studies showed that heavy metals have deleterious impacts on the environment due to their mobility nature; some of the heavy metals are mobile in nature, moving from soil to plants and underground water and circulating through the entire food chain. leading to indirect effects on the health of human [2].

Many countries have taken measures to judge the extent to which soil is contaminated with heavy metals. These scales vary according to the environment of the country issuing those standards. States whose territories are acidic are more stringent of those that fall under dry and semi-dry conditions, where there are alkaline soils. This difference is due to the fact that the heavy elements are less soluble 
and can move in alkaline soils [3]. Monitoring of environmental quality around brick factories should be of a main importance. Regular monitoring can help to evaluate the extent or trend of pollution and can also suggest some controlling measures as well as possible remediation [4].

Urbanization is one of the main impact factors in the development of countries. In developing countries, especially Iraq, as the population accelerates, the rate of urbanization is also increasing. Demand for the construction of brick kilns is also increasing in major urban areas.

The production rate of the Abu Smeache block in the area of AL-Kifl is about 12 million blocks per year, while the amount of fuel consumed ranges from 150 to 170 thousand liters during the annual production period. Also, the design of the incinerator, the characteristics of the fuel and its incomplete combustion at the beginning of the burning period, as well as the non-control of emissions, contribute to the release of different pollutants. The availability of clay, water, and labor are the main features that have led to the establishment of a large number of block factories in this region.

Studies on factories' effects as a major source of environmental pollution in AL-Kifl are not very common. Few studies were carried out in order to assess the effects of brick kilns on soil and plants in other areas in Iraq. One of these studies (Shanshal, 2004) found high concentrations of heavy metals $(\mathrm{Cd}, \mathrm{Ni}, \mathrm{Pb}, \mathrm{Cr})$ in the soil of Nahrawan area, along with high concentrations of high heavy elements in the tissues of Schanginia plant in the same area, and attributed the increase to the presence of tanning plants and brick factories. Another study (Al- Kawaz, 2017) on the effects of factories smoke on the plant species Dodonaea viscosa and Conocarpus lancifolius showed high concentrations of lead and cadmium in plants, soil, dust and water used in irrigation at the affected site compared with the unaffected site[5]. However, no studies are available that evaluate the situation through conducting an environmental assessment and evaluating the extent of pollutants within the factories and their transfer to residential areas and the groundwater nearby. This is especially critical due to the presence of a religious shrine up to $4 \mathrm{~km}$ from the region, which led to its development as a residential area. The current investigation reveals the results collected in one year, with a purpose of understanding the impact of heavy metal pollution on the soil and air in the factories, as well as the extent of its spread to nearby lands.

\section{1-1 Geological Setting:}

According to the Buday's division, Al-Kifl area lies in the unstable shelf within the Mesopotamian zone and in the Euphrates subzone. It represents the boundary between stable and unstable shelves [6]. The study area is bound by Desert of Najaf from the west, Euphrates river from the east, Karbala city from the north, and Khan AL-Rahha from the south. The gradational deposits of the Euphrates river which originate the delta plain represent the limits of the east part [7], as shown in Figure-1

The geology and tectonic evolution of Iraq was greatly influenced by the opening and closing of the Palaeotethys and Neotethys oceans. The Neotethys was opened during the Upper Carboniferous Permian along the rifting axis that runs parallel to Zagros.The Mesopotamian intercontinental basin was developed inside the Arabian plate and to the west of Zagros thrust depth [8]. Consequently, ALKifl area was affected by this evolution and was located on the west flank of the Mesopotamian basin. The transversal faults played their rules in the depositional basin environment and later on in the developing of the main tectonic structures. It seems that these faults have been active since the Permian times [8] 


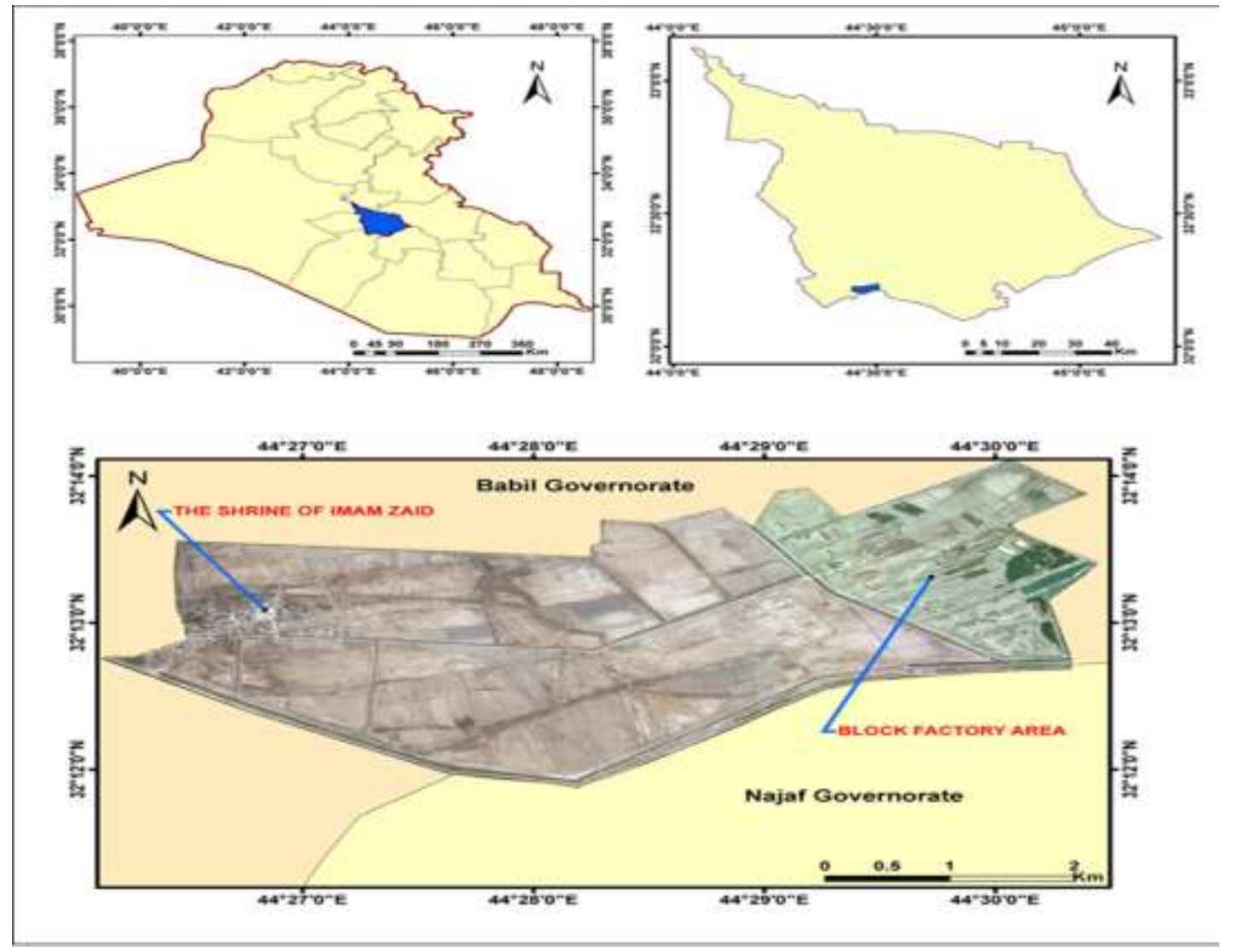

Figure 1- Location Map of study area

\section{2-Materials and methods \\ 2-1 Study area}

The industrial Abu Smeache is located east of Al-Kifl district, affiliated to the city of Hilla (16 km south of Hilla). The present study area covers (15.59937) $\mathrm{km}^{2}$. Al-Kifl district represents the road between Hilla and Najaf cities and characterized by the existence of agricultural areas, which depend on the Euphrates river and various branches and drainage channels. The area occupied by the factories is $3.375 \mathrm{~km}^{2}$, located at the latitude $32^{\circ} 15^{\prime} 52.9$ and the longitude $44^{\circ} 49^{\prime} 02.3$ ", with a large number of brick factories, each of which occupying an area of 50-70. An increasing number of these factories has been observed to be established on this specific area .

\section{2-2 Field and Sampling Works}

Samples of air were taken from 8 stations (inside and outside the brick factories) distributed in different areas within the Abu Smeache. The stations were selected for the purpose of measuring the concentrations of total suspended particles (TSP) and gases $\left(\mathrm{CO}, \mathrm{CO}_{2}, \mathrm{NO}_{2}, \mathrm{SO}_{2}\right)$. The study was designed to include stations that cover most of the area during two periods, winter 2017 and summer 2018, as shown in Figure-2 and Table-1. A sniffer measuring device was used in the modeling process, where the device was installed and operated for one hour and at a height not less than one meter

The soil sampling process was carried out by identifying 10 sampling sites inside and around the factories, for soils exposed, undisturbed or exposed to other human activities (such as sewage) as shown in Figure-2 and Table-2. A hand Auger device was used to collect soil samples. Two samples of each site were taken, representing surface (depth $0-10 \mathrm{~cm}$ ) and sub-surface (depth $10-20 \mathrm{~cm}$ ) samples. Each samples was placed in a plastic bag and sent to the laboratory for the necessary analysis. 


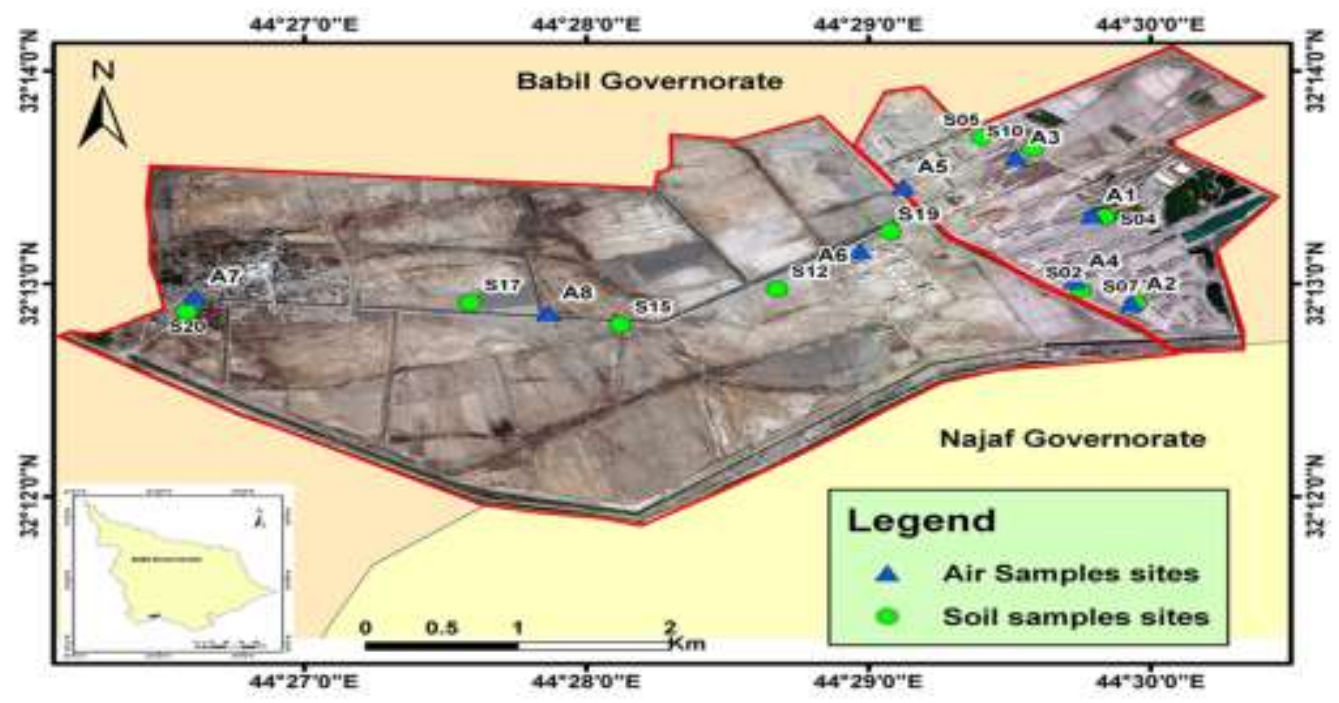

Figure 2-Air and Soil samples location of the study area

Table 1-Geographic coordination of Air samples location

\begin{tabular}{|c|c|c|c|c|}
\hline Num. & Code sample & Station & E & N \\
\hline $\mathbf{1}$ & $\mathbf{A 1}$ & Inside Bricks factory & 44.4965 & 32.2220 \\
\hline $\mathbf{2}$ & $\mathbf{A 2}$ & Inside Bricks factory & 44.4989 & 32.2151 \\
\hline $\mathbf{3}$ & $\mathbf{A 3}$ & Inside Bricks factory & 44.4920 & 32.2266 \\
\hline $\mathbf{4}$ & $\mathbf{A 4}$ & Inside Bricks factory & 44.4955 & 32.2169 \\
\hline $\mathbf{5}$ & $\mathbf{A 5}$ & Outside the factories & 44.4854 & 32.2243 \\
\hline $\mathbf{6}$ & $\mathbf{A 6}$ & Outside the factories & 44.4829 & 32.2192 \\
\hline $\mathbf{7}$ & $\mathbf{A 7}$ & Outside the factories & 44.4436 & 32.2157 \\
\hline $\mathbf{8}$ & $\mathbf{A 8}$ & Outside the factories & 44.4644 & 32.2144 \\
\hline
\end{tabular}

Table 2-Geographic coordination of Soil samples location

\begin{tabular}{|c|c|c|c|c|}
\hline Num. & Code sample & Station & E & N \\
\hline $\mathbf{1}$ & $\mathbf{A 0 2}$ & Inside Bricks factory & 44.4958 & 32.2161 \\
\hline $\mathbf{2}$ & $\mathbf{A 0 4}$ & Inside Bricks factory & 44.4973 & 32.2219 \\
\hline $\mathbf{3}$ & $\mathbf{A 0 5}$ & Inside Bricks factory & 44.4900 & 32.2281 \\
\hline $\mathbf{4}$ & $\mathbf{A 0 7}$ & Inside Bricks factory & 44.4991 & 32.2150 \\
\hline $\mathbf{5}$ & $\mathbf{A 1 0}$ & Inside Bricks factory & 44.4930 & 32.2272 \\
\hline $\mathbf{6}$ & $\mathbf{A 1 2}$ & Outside the factories & 44.4779 & 32.2162 \\
\hline $\mathbf{7}$ & $\mathbf{A 1 5}$ & Outside the factories & 44.4686 & 32.2134 \\
\hline $\mathbf{8}$ & $\mathbf{A 1 7}$ & Outside the factories & 44.4598 & 32.2151 \\
\hline $\mathbf{9}$ & $\mathbf{A 1 9}$ & Outside the factories & 44.4841 & 32.2207 \\
\hline $\mathbf{1 0}$ & $\mathbf{A 2 0}$ & Outside the factories & 44.4430 & 32.2144 \\
\hline
\end{tabular}

\section{2-3 Laboratory Works}

A digestion process of soil samples for heavy metals determination was conducted according to the procedure described by Sharidah [9] by using nitric acid and perchloric acid. Air and soil samples were examined by Atomic absorption spectroscopy (A.A.S) for trace elements in the lab of the Iraq 
Ministry of Science and Technology, Baghdad. The following factors were applied to assess the level of soil pollution in the study area:

\section{1- Contamination factor (CF) and Pollution Load Index (PLI)}

The PLI was derived from the calculated value of the CF, which was used to classify the level of contamination with metals in the soil and river sediment samples. The quotient was obtained by dividing the concentration of each metal on background value of that metal. The PLI of each site was calculated by obtaining the n-root for the n- CFs that was obtained for all the metals [10]. The PLI was calculated according to Tomlinson et al [11], as follows:

$\mathrm{CF}=\mathrm{C}$ metal $/ \mathrm{C}$ background value

Where:

$$
\text { PLI }=n \sqrt{ }(\text { CF } 1 \times C F 2 \times C F 3 x \ldots x C F n)
$$

$\mathrm{CF}=$ Contamination factor, $\mathrm{n}=$ Number of metals .

$\mathrm{C}$ metal $=$ Metal concentration in polluted sediments .

$\mathrm{C}$ Background value $=$ Background value of that metal.

The Contamination Factor was classified according to [12] into:

\begin{tabular}{l|l}
$C F-V a l u e$ & Pollution \\
$C F=1$ & Mon \\
$1=C F=3$ & Moderate \\
$3=C F=-6$ & Very high
\end{tabular}

The PLI value was classified according to [13] into:

\begin{tabular}{l|l} 
PLI Value & Pollution \\
\hline 0 & Perfection \\
$>1$ & $\begin{array}{l}\text { Baseline Level } \\
\text { Polluted }\end{array}$
\end{tabular}

2- Geo-accumulation index (I-geo)

Enrichment of metal concentrations above baseline levels was calculated using a previously proposed method [14], termed the geo accumulation index (Igeo). Geo-accumulation index was determined by the following an equation based on previous reports $[15,16]$

$$
\operatorname{I-geo}=\operatorname{Ln}(\mathrm{Cn} / 1.5 \mathrm{Bn})
$$

Where: $\mathrm{Cn}=$ Measured concentration of heavy metal in the soil.

$\mathrm{Bn}=$ Geochemical background value according to [17] of element $\mathrm{n}$. The factor 1.5 is used for the possible variations of the background data due to lithological variations.

I-geo was classified into seven grades, according to [18]:

\begin{tabular}{l|l}
$I_{\text {Heo }}$ & $I_{\text {noo }}$ grade \\
\hline $20-0$ & 0 \\
$0-1$ & 1 \\
$1-2$ & 2 \\
$2-3$ & 3 \\
$3-4$ & 4 \\
$4-5$ & 5 \\
$5-6$ & $>5$
\end{tabular}

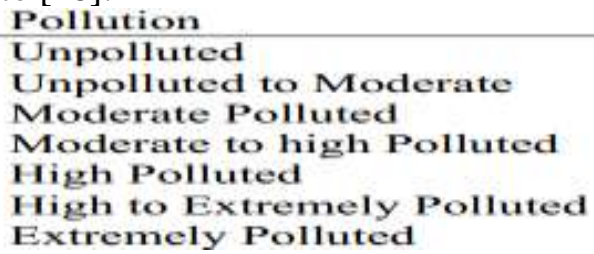

\section{3-Results and discussion}

\section{3-1 Air}

The results of air pollutant concentrations in Abu Smeache area are shown in Tables- 3 and 4. The mean concentrations of total suspended particulate (TSP) in both seasons (summer and winter) were high, exceeding the limits allowed globally and nationally, whereas the mean concentrations of $\mathrm{SO}_{2}$ increased during the winter, but in the summer they were within the global and national limits. Sulfurderived gases act in the atmosphere as a layer preventing the entry of sun radiation and the exit of earth radiation [1 ]. There was also a small increase in the ratio of $\mathrm{NO}_{2}$ inside the factories area during summer and winter periods, whereas the concentration of this gas outside was within the limits allowed. It was also found that most of the concentrations of the other gases $\left(\mathrm{CO}_{2}, \mathrm{CO}\right)$ did not exceed the limits allowed. The examination of heavy elements in the air showed a large increase in the concentrations of lead in the atmosphere, while those of cobalt and nickel were lower but generally higher than the limits allowed Figures-(3 and 4). 
Table 3-Concentrations of gases, TSP, heavy elements in the air of study area comparing with local and world limits. (for summer Season)

\begin{tabular}{|c|c|c|c|c|c|c|c|c|}
\hline Station & $\begin{array}{c}\text { TSP } \\
(\mu \mathrm{g} / \mathrm{m} 3)\end{array}$ & $\begin{array}{c}\text { CO } \\
\text { PPM }\end{array}$ & $\begin{array}{l}\mathrm{CO2} \\
\text { PPM }\end{array}$ & $\begin{array}{l}\text { NO2 } \\
\text { PPM } \\
\end{array}$ & $\begin{array}{l}\text { SO2 } \\
\text { PPM }\end{array}$ & $\begin{array}{c}\mathrm{Pb} \\
(\mu \mathrm{g} / \mathrm{m} 3)\end{array}$ & $\begin{array}{c}\mathrm{Ni} \\
(\mu \mathrm{g} / \mathrm{m} 3)\end{array}$ & $\begin{array}{c}\text { Co } \\
(\mu \mathrm{g} / \mathrm{m} 3)\end{array}$ \\
\hline A1 & 229.691 & 10.42 & 79.5 & 1.7 & 0 & 5.536 & 1.045 & 0.578 \\
\hline A2 & 196.078 & 10.7 & 79 & 1.5 & 0 & 5.714 & 1.251 & 0.345 \\
\hline A3 & 561.660 & 1.4 & 64.3 & 0.25 & 0 & 4.468 & 1.794 & 1.001 \\
\hline A4 & 654.456 & 1.33 & 50.3 & 0.25 & 0 & 9.523 & 1.538 & 0.659 \\
\hline A5 & 751.322 & 8.42 & 78.875 & 0.15 & 0.1 & 2.264 & 2.095 & 0.772 \\
\hline A6 & 554.334 & 0 & 68 & 0 & 0 & 10.512 & 2.100 & 0.561 \\
\hline A7 & 757.020 & 0 & 45 & 0 & 0 & 11.233 & 2.478 & 1.111 \\
\hline A8 & 296.296 & 9.2 & 45 & 0.15 & 0 & 8.148 & 2.084 & 0.264 \\
\hline Mean & 500.107 & 5.18 & 63.74 & 0.5 & 0.0125 & 7.175 & 1.798 & 0.661 \\
\hline Range & $\begin{array}{c}196.078- \\
757.020 \\
\end{array}$ & $\begin{array}{c}0- \\
10.42\end{array}$ & $\begin{array}{l}45- \\
79.5\end{array}$ & $0-1.7$ & $0-0.1$ & $2.264-11.233$ & $1.045-2.478$ & $\begin{array}{c}0.264- \\
1.111\end{array}$ \\
\hline WHO, 1996 & 150 & 9 & 250 & 0.11 & 0.01 & 0.5 & & \\
\hline EPA, 2005 & & 35 & & 0.53 & & 0.15 & & \\
\hline $\begin{array}{c}\text { Iraqi } \\
\text { standard, } \\
2008\end{array}$ & 350 & 35 & 250 & 0.25 & 0.14 & 3 & 0.2 & \\
\hline
\end{tabular}

Table 4-Concentrations of gases ,TSP, heavy elements in the air of study area comparing with local and world limits. (for winter Season)

\begin{tabular}{|c|c|c|c|c|c|c|c|c|}
\hline Station & $\begin{array}{c}\text { TSP } \\
(\mu \mathrm{g} / \mathrm{m} 3)\end{array}$ & $\begin{array}{c}\text { CO } \\
\text { PPM }\end{array}$ & $\begin{array}{l}\text { CO2 } \\
\text { PPM }\end{array}$ & $\begin{array}{l}\text { NO2 } \\
\text { PPM }\end{array}$ & $\begin{array}{l}\text { SO2 } \\
\text { PPM }\end{array}$ & $\begin{array}{c}\text { Pb } \\
(\mu \mathrm{g} / \mathrm{m} 3)\end{array}$ & $\begin{array}{c}\mathbf{N i} \\
(\mu \mathrm{g} / \mathrm{m} 3)\end{array}$ & $\begin{array}{c}\text { Co } \\
(\mu \mathrm{g} / \mathrm{m} 3)\end{array}$ \\
\hline A1 & 1532.275 & 2.3 & 25 & 0.3 & 0.45 & 3.153 & 1.481 & 0.825 \\
\hline $\mathbf{A 2}$ & 814.192 & 5 & 50 & 0.2 & 0.4 & 2.539 & 1.419 & 0.887 \\
\hline A3 & 1756.613 & 2.5 & 38 & 0.3 & 0.5 & 2.627 & 1.507 & 0.987 \\
\hline A4 & 984.126 & 1.8 & 50 & 0.2 & 0.4 & 8.219 & 1.269 & 2.210 \\
\hline A5 & 213.868 & 2.1 & 35 & 0.15 & 0.25 & 4.436 & 1.629 & 1.779 \\
\hline A6 & 452.798 & 2.4 & 54 & 0.1 & 0.2 & 3.458 & 0.877 & 1.746 \\
\hline A7 & 2267.573 & 2.5 & 94 & 0.1 & 0.2 & 6.757 & 2.505 & 3.072 \\
\hline A8 & 321.195 & 2.4 & 122 & 0.2 & 0.3 & 5.686 & 1.932 & 1.858 \\
\hline Mean & 1042.830 & 2.625 & 58.5 & 0.193 & 0.337 & 4.609 & 1.577 & 1.670 \\
\hline Range & $\begin{array}{c}213.868- \\
2267.573\end{array}$ & $1.8-5$ & $\begin{array}{l}25- \\
122 \\
\end{array}$ & $0.1-0.3$ & $\begin{array}{l}0.2- \\
0.45 \\
\end{array}$ & $\begin{array}{c}2.539- \\
8.219 \\
\end{array}$ & $0.877-2.505$ & $0.825-3.072$ \\
\hline WHO, 1996 & 150 & 9 & 250 & 0.11 & 0.01 & 0.5 & & \\
\hline EPA, 2005 & & 35 & & 0.53 & & 0.15 & & \\
\hline $\begin{array}{c}\text { Iraqi } \\
\text { standard, } \\
2008 \\
\end{array}$ & 350 & 35 & 250 & 0.25 & 0.14 & 3 & 0.2 & \\
\hline
\end{tabular}





Figure 3: Map Concentrations of TSP, gases, heavy elements in the air of study area for summer Season

\section{3-2 Soil samples}

The accumulation of heavy metals in surface soils is affected by many environmental variables, including parent materials and soil properties, as well as human activities such as industrial production, traffic, farming, and irrigation. Large areas can be contaminated by heavy metals released from smelters, waste incinerators, industrial wastewater, and from the application of sludge or municipal compost, pesticides, and fertilizers. Irrespective of their sources in the soil, accumulation of heavy metals can degrade soil quality, reduce crop yield and the quality of agricultural products, and thus negatively impact the health of human, animals, and the ecosystem [19]. The diagram in Figure-5 shows a comparison of heavy metal concentrations in the soil in depth $A$ and $B(A=0-10 \mathrm{~cm}, B=10$ $20 \mathrm{~cm}$ ). Table- 5 compares total concentrations of each heavy metal in the tested soil samples, which were found to following order: $\mathrm{Pb}>\mathrm{Ni}>\mathrm{Co}$.

The heavy metals are present in considerable amounts in the soil. This may be due to the wide use of chemicals containing heavy metals being discharged into the environment as a result of the use of crude oil in industrial activities [20]. Soil contamination with heavy elements is a measure of environmental pollution. Increasing the soil content of some rare elements leads to diseases due to soil containment of high levels of lead [21]. Studies indicated that heterogeneity in the content of rocks forming the earth's crust, which leads to changes in the levels of soil constituents, is due to the geochemical factors that dominate soil formation. Therefore, increasing the concentration of elements, 
especially trace elements, results in soil contamination [22]. The distribution of heavy metals in sediments depends on the nature of the element (ion or composition), its physical and chemical properties, the presence of clay minerals (adsorbents and filters), the organic matter (which helps to attract the elements), and soil $\mathrm{pH}$. The stability of the metal in the soil depends on the $\mathrm{pH}$ of the soil and the nature of the clay. Also, the low-rainfall areas with dry climates have a low movement of heavy elements compared to areas with heavy rain where the movement of solutions is greater [22].

The mean concentration of lead in the topsoil $(0-10 \mathrm{~cm})$ was about $187.067 \mathrm{ppm}$, while its mean concentration in sub-surface soil $(10-20 \mathrm{~cm})$ was about $162.294 \mathrm{ppm}$ (Table-5), Figures-(6 and 7). These concentrations were higher than that in the shale rocks (20 ppm) reported by Krauskopf in 1967 [23], and higher than the determinants recorded by Kabata-Pendias and Mukherjee in 2007, which had a value of 25ppm [24]. It was also observed that lead concentrations in the surface soils were higher than those in the sub-surface soils. The reason for this difference is that lead is adsorbed on the surfaces of clay minerals and may be captured within the potash feldspar [25]. It is also adsorbed by the surfaces of iron oxides and manganese, while the lack of rainfall in the region leads to the persistence of its concentrations high in the surface layer, and in general, lead is found in the soil more than in the rocks [26]. The increase of lead concentrations in the soil of the study area might also be due to its increase in the air of the region as a result of its presence in the smoke of the factories which falls on the soil [22].

The mean concentration of nickel in the surface soil of the region was $19.59 \mathrm{ppm}$ while in subsurface soil was $17.95 \mathrm{ppm}$ (Table -5 , Figures-(6 and 7), both of which were significantly lower than those in the shale (95 ppm), as reported by Krauskopf in 1967 [23]. However, these concentrations exceeded the global determinants of soil (18 ppm), described by Kabata-Pendias and Mukherjee [24], especially in the surface layer (Figure-4). Nickel generally shows different concentrations in different soils, where arid and semi-arid soil contains higher concentrations than tropical and temperate cold areas. The soil content of nickel is mainly related to the source rocks, with a secondary relationship with each of the following factors: soil quality, degree of development, fine fraction, moisture content and organic matter. The reason for the increase in nickel concentration in the soil of the study area might be the adsorption of clay minerals, especially montormorlonite, which is a clay ore prevalent in the soil of arid and semi-arid regions of the country [22]. Montormorlonites are stable and non-ionic exchangeable materials that act as a filter for the heavy elements that they absorb, and they have the ability to enter the crystal structure.

he mean concentration of cobalt $6.20 \mathrm{ppm}$ in the surface soil and $8.15 \mathrm{ppm}$ in the sub-surface soil (Table-5, Figures-( 6 and 7). The average of its presence in the lithosphere was reported to be about 30 ppm and its content in the soil was 0.05-300 ppm [22]. Its concentrations in the subsurface soils in the present study record $(18 \mathrm{ppm})$ that exceeded the global determinants by Kabata-Pendias and Mukherjee [24] which record (6.9 ppm), while the concentration of the cobalt in surface soils was below these limits. Soil content of cobalt depends on the source rocks, their degree of absorption, the type of soil, and the climate of the region or geographical range. Its presence in the soil also depends on the presence of the organic matter (humus), which is very adsorbent; this may increase its concentration in depth(B) as commonly occurs in Podzol soils. Studies indicated that the oxidation and reduction processes have an effect of increasing cobalt concentrations, with basal soils are rich in cobalt relative to acid soils due to increased transition.[22]

Table 5- shows the results of total concentration of heavy metals in the tested soil samples in the surface $\mathrm{A}(0-10 \mathrm{~cm})$ and under the surface $\mathrm{B}(10-20 \mathrm{~cm})$ comparison to the other studies

\begin{tabular}{|c|c|c|c|c|c|c|c|}
\hline \multirow{2}{*}{ Num. } & \multirow{2}{*}{ Cod } & \multicolumn{2}{|c|}{ Pb ppm } & \multicolumn{2}{c|}{ Ni ppm } & \multicolumn{2}{c|}{ Co ppm } \\
\cline { 3 - 8 } & & depth A & depth B & depth A & depth B & depth A & depth B \\
\hline 1 & A02 & 203.265 & 177.85 & 22.47 & 22.82 & 1.32 & 10.02 \\
\hline $\mathbf{2}$ & A04 & 195.325 & 165.15 & 19.55 & 16.47 & 5.97 & 8.55 \\
\hline 3 & A05 & 182.62 & 193.73 & 24.87 & 13.57 & 5.85 & 6.10 \\
\hline 4 & A07 & 169.91 & 166.74 & 21.82 & 13.17 & 3.52 & 5.37 \\
\hline $\mathbf{5}$ & A10 & 217.55 & 211.20 & 18.27 & 16.72 & 5.85 & 4.87 \\
\hline 6 & A12 & 168.32 & 198.50 & 22.80 & 22.17 & 10.37 & 7.20 \\
\hline 7 & A15 & 177.85 & 204.85 & 13.37 & 24.87 & 4.025 & 7.07 \\
\hline 8 & A17 & 204.85 & 157.21 & 20.22 & 19.52 & 8.30 & 4.02 \\
\hline
\end{tabular}




\begin{tabular}{|c|c|c|c|c|c|c|c|}
\hline 9 & A19 & 160.38 & 125.45 & 11.22 & 10.20 & 4.40 & 4.15 \\
\hline 10 & A20 & 190.56 & 22.23 & 21.32 & 19.95 & 12.40 & 24.2 \\
\hline \multicolumn{2}{|c|}{ Mean } & 187.06 & 162.29 & 19.59 & 17.94 & 6.20 & 8.15 \\
\hline \multicolumn{2}{|c|}{ Range } & $160.38-217.55$ & $22.23-211.2$ & $11.22-24.87$ & $10.20-28.87$ & $1.32-12.40$ & $4.02-24.2$ \\
\hline \multicolumn{2}{|c|}{$\begin{array}{l}\text { Kabata-Pendias and } \\
\text { Mukherjee, } 2007\end{array}$} & \multicolumn{2}{|c|}{25} & \multicolumn{2}{|c|}{18} & \multicolumn{2}{|c|}{6.9} \\
\hline \multicolumn{2}{|c|}{ WHO,2006 } & \multicolumn{2}{|c|}{$50-300$} & \multicolumn{2}{|c|}{$30-75$} & \multicolumn{2}{|c|}{-} \\
\hline \multicolumn{2}{|c|}{$\begin{array}{c}\text { Al_Sultany, } \\
2006\end{array}$} & \multicolumn{2}{|c|}{62.3} & \multicolumn{2}{|c|}{174.6} & \multicolumn{2}{|c|}{12.6} \\
\hline \multicolumn{2}{|c|}{ Al-Maliky,2005 } & \multicolumn{2}{|c|}{153.7} & \multicolumn{2}{|c|}{111.4} & \multicolumn{2}{|c|}{-} \\
\hline \multicolumn{2}{|c|}{ Shanshal ,2004 } & \multicolumn{2}{|c|}{41} & \multicolumn{2}{|c|}{111} & \multicolumn{2}{|c|}{-} \\
\hline
\end{tabular}

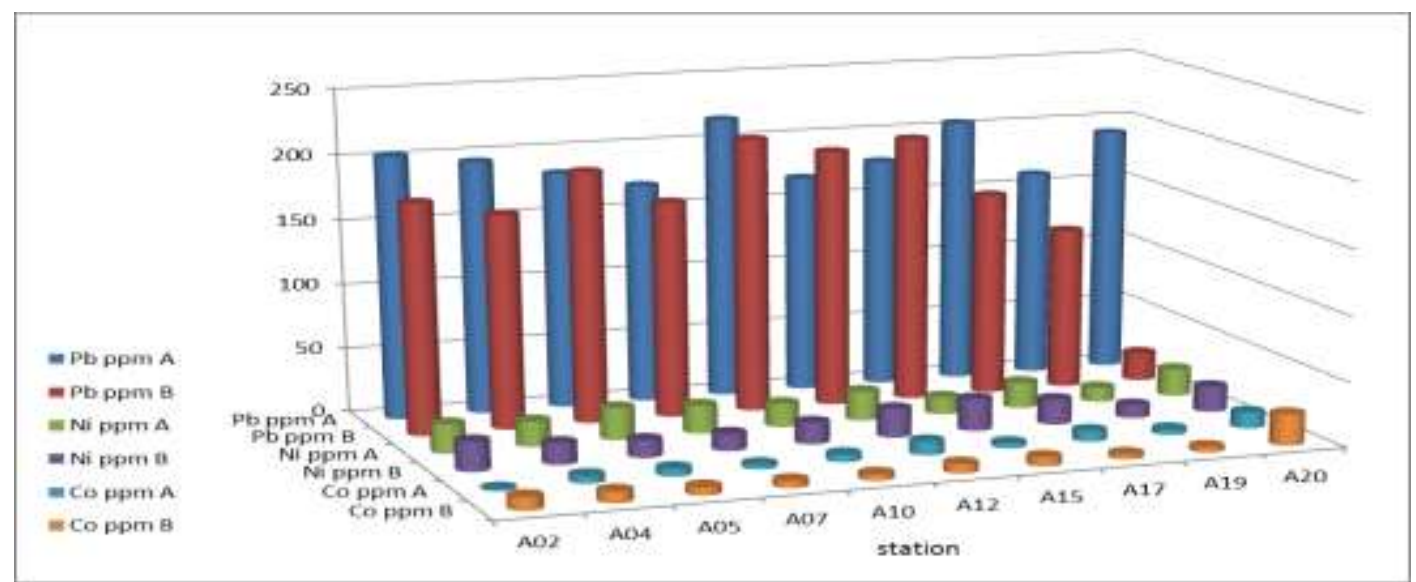

Figure 5-diagram shape for the heavy metals in the soil of study area for comparison between concentration in depth A and $B(A=0-10 \mathrm{~cm}, B=10-20 \mathrm{~cm})$.

\section{3-3 Contamination Index for Soil}

\section{1- Contamination Factor and Pollution Load Index}

Pollution severity and its variation along the sites were determined with the use of pollution load index. This index is a quick tool in order to compare the pollution status of different places [27]. Table- 6 and Figures- $(6$ and 7$)$ show that the values of contamination factor for lead indicated very high pollution in all sites, except for the sub-surface layer in stations A19 and A20 of zone B (5.0181 and 0.8893, respectively) which are classified as a considerably polluted and low polluted, respectively. $\mathrm{CF}$ values for $\mathrm{Ni}$ and $\mathrm{Co}$ ranged between low to moderate contamination, except for site A20 (zone B) which showed considerable pollution. Abundance of these elements in sediments depends on many factors such as the function of clay fraction, soil organic matter (O.M), as well as other physico-chemical conditions such as Eh and $\mathrm{pH}$. Therefore, argillaceous sediments contain more heavy elements (e.g., $\mathrm{Pb}$ ) than sands, sandstones and limestones [28]. Many stations can be classified as pollution areas; stations with PLI values $>1$ confirm their considerable contamination, while the few others have PLI values $<1$.Variation of PLI of sampling stations is shown in Table- 6 and Figure5. These results may be due to the presence of many pollutants in the area. PLI value close to 1 indicates heavy metal loads near the background level, while values above 1 indicate soil pollution. As modified and generalized form of Hakanson (1980), the equation for the calculation of the overall degree of contamination was defined as the sum of all contamination factors (CF) for a given set of pollutants divided by the number of analyzed pollutants [29].

Table 6-CF values and PLI Value of Heavy metals in the Study area

\begin{tabular}{|c|c|c|c|c|c|c|c|c|c|c|}
\hline \multirow{2}{*}{$\begin{array}{c}\text { Num } \\
\cdot\end{array}$} & \multirow{2}{*}{ Cod } & \multirow{2}{*}{ depth } & \multicolumn{9}{|c|}{ CF } & Pb & Decision & Ni & Decision & Co & Decision & \multirow{2}{*}{ PLI } & \multirow{2}{*}{ Decision } \\
\hline $\mathbf{1}$ & $\mathbf{A 0 2}$ & A & 8.1306 & Very high & 1.2487 & Moderate & 0.1920 & low & 1.2492 & polluted \\
\hline & & B & 7.1143 & Very high & 1.2680 & Moderate & 1.4532 & Moderate & 2.3579 & polluted \\
\hline $\mathbf{2}$ & $\mathbf{A 0 4}$ & A & 7.813 & Very high & 1.0862 & Moderate & 0.8659 & low & 1.7237 & polluted \\
\hline
\end{tabular}




\begin{tabular}{|c|c|c|c|c|c|c|c|c|c|c|}
\hline & & B & 6.6061 & Very high & 0.9152 & low & 1.2391 & Moderate & 1.9808 & polluted \\
\hline $\mathbf{3}$ & A05 & A & 7.3048 & Very high & 1.3820 & Moderate & 0.8748 & low & 1.9442 & polluted \\
\hline & & B & 7.7495 & Very high & 0.7541 & low & 0.8840 & low & 1.9567 & polluted \\
\hline $\mathbf{4}$ & A07 & A & 6.7967 & Very high & 1.2125 & Moderate & 0.5108 & low & 2.0455 & polluted \\
\hline & & B & 6.6696 & Very high & 0.7319 & low & 0.7789 & low & 1.7287 & polluted \\
\hline $\mathbf{5}$ & A10 & A & 8.7023 & Very high & 1.0152 & Moderate & 0.8478 & low & 1.4886 & polluted \\
\hline & & B & 8.4482 & Very high & 0.9291 & low & 0.7065 & low & 1.9685 & polluted \\
\hline $\mathbf{6}$ & A12 & A & 6.7331 & Very high & 1.2666 & Moderate & 1.5036 & Moderate & 1.6147 & polluted \\
\hline & & B & 7.94 & Very high & 1.2319 & Moderate & 1.0434 & Moderate & 1.5608 & polluted \\
\hline $\mathbf{7}$ & A15 & A & 7.1143 & Very high & 0.7430 & low & 0.5833 & low & 1.2205 & polluted \\
\hline & & B & 8.1941 & Very high & 1.3819 & Moderate & 1.0253 & Moderate & 1.6639 & polluted \\
\hline $\mathbf{8}$ & A17 & A & 8.1941 & Very high & 1.1236 & Moderate & 1.2028 & Moderate & 1.4908 & polluted \\
\hline & & B & 6.2884 & Very high & 1.0847 & Moderate & 0.5833 & low & 2.0668 & polluted \\
\hline $\mathbf{9}$ & A19 & A & 6.4155 & Very high & 0.6236 & low & 0.6376 & low & 1.9566 & polluted \\
\hline & & B & 5.0181 & considerable & 0.5666 & low & 0.6014 & low & 1.7700 & polluted \\
\hline $\mathbf{1 0}$ & A20 & A & 7.6224 & Very high & 1.1847 & Moderate & 1.7971 & Moderate & 0.8112 & Baseline level \\
\hline & & B & 0.8893 & low & 1.1083 & Moderate & 3.5072 & considerable & 0.5900 & Baseline level \\
\hline
\end{tabular}

\section{2- Geo-accumulation index (I-Geo)}

Using the I-geo to measure the enrichment of metals above baseline concentrations, sediments were classified as a moderately polluted with $\mathrm{Pb}$, except for the sub-surface layer in station A20 of zone B, which reached a value of- 0.5227 that classifies it as unpolluted. Sediments were unpolluted with Ni and Co, except sites A12 (zone A) and A 20 (zones A, B) which were classified as unpolluted to moderate (Table-7 and Figures-(6 and 7).

Table 7-I-Geo values of Heavy metals in the Study area

\begin{tabular}{|c|c|c|c|c|c|c|c|c|}
\hline \multirow{2}{*}{ Num. } & \multirow{2}{*}{ Cod } & \multirow{2}{*}{ depth } & \multicolumn{6}{|c|}{ I-Geo } \\
\hline & & & $\mathbf{P b}$ & Decision & $\mathbf{N i}$ & Decision & Co & Decision \\
\hline \multirow[t]{2}{*}{1} & $\begin{array}{c}\text { A0 } \\
2\end{array}$ & A & 1.6901 & $\begin{array}{c}\text { Moderate } \\
\text { Polluted }\end{array}$ & -0.1833 & unpolluted & -2.0555 & unpolluted \\
\hline & & B & 1.5566 & $\begin{array}{c}\text { Moderate } \\
\text { Polluted }\end{array}$ & -0.1679 & unpolluted & -0.0316 & unpolluted \\
\hline \multirow[t]{2}{*}{2} & $\begin{array}{c}\text { A0 } \\
4\end{array}$ & A & 1.6503 & $\begin{array}{c}\text { Moderate } \\
\text { Polluted }\end{array}$ & -0.3227 & unpolluted & -0.5494 & unpolluted \\
\hline & & B & 1.4825 & $\begin{array}{c}\text { Moderate } \\
\text { Polluted }\end{array}$ & -0.4939 & unpolluted & -0.1910 & unpolluted \\
\hline \multirow[t]{2}{*}{3} & $\begin{array}{c}\text { A0 } \\
5\end{array}$ & A & 1.5830 & $\begin{array}{c}\text { Moderate } \\
\text { Polluted }\end{array}$ & -0.0818 & unpolluted & -0.5705 & unpolluted \\
\hline & & B & 1.6421 & $\begin{array}{c}\text { Moderate } \\
\text { Polluted } \\
\end{array}$ & -0.6876 & unpolluted & -0.5286 & unpolluted \\
\hline \multirow[t]{2}{*}{4} & $\begin{array}{c}\text { A0 } \\
7\end{array}$ & A & 1.5109 & $\begin{array}{c}\text { Moderate } \\
\text { Polluted }\end{array}$ & -0.2127 & unpolluted & - 1.0771 & unpolluted \\
\hline & & B & 1.4920 & $\begin{array}{c}\text { Moderate } \\
\text { Polluted }\end{array}$ & -0.7175 & unpolluted & -0.6552 & unpolluted \\
\hline \multirow[t]{2}{*}{5} & $\begin{array}{c}\mathbf{A 1} \\
\mathbf{0}\end{array}$ & A & 1.7581 & $\begin{array}{c}\text { Moderate } \\
\text { Polluted }\end{array}$ & -0.3903 & unpolluted & -0.5705 & unpolluted \\
\hline & & B & 1.7284 & $\begin{array}{c}\text { Moderate } \\
\text { Polluted } \\
\end{array}$ & -0.4789 & unpolluted & -0.7528 & unpolluted \\
\hline \multirow[t]{2}{*}{6} & $\begin{array}{c}\mathbf{A 1} \\
\mathbf{2}\end{array}$ & A & 1.5015 & $\begin{array}{c}\text { Moderate } \\
\text { Polluted }\end{array}$ & -0.1690 & unpolluted & 0.0024 & Unpolluted to Moderate \\
\hline & & B & 1.6664 & $\begin{array}{c}\text { Moderate } \\
\text { Polluted }\end{array}$ & -0.1968 & unpolluted & -0.3629 & unpolluted \\
\hline \multirow[t]{2}{*}{7} & $\begin{array}{c}\mathbf{A 1} \\
5\end{array}$ & A & 1.5566 & $\begin{array}{c}\text { Moderate } \\
\text { Polluted }\end{array}$ & -0.7024 & unpolluted & -0.9444 & unpolluted \\
\hline & & B & 1.6979 & $\begin{array}{c}\text { Moderate } \\
\text { Polluted }\end{array}$ & -0.0819 & unpolluted & -0.3804 & unpolluted \\
\hline
\end{tabular}




\begin{tabular}{|c|c|c|c|c|c|c|c|c|}
\hline $\mathbf{8}$ & $\begin{array}{c}\text { A1 } \\
\mathbf{7}\end{array}$ & A & 1.6979 & $\begin{array}{c}\text { Moderate } \\
\text { Polluted }\end{array}$ & -0.2889 & unpolluted & -0.2207 & unpolluted \\
\hline $\mathbf{9}$ & $\begin{array}{c}\mathbf{A 1} \\
\mathbf{9}\end{array}$ & $\mathrm{A}$ & 1.4532 & $\begin{array}{c}\text { Moderate } \\
\text { Polluted }\end{array}$ & -0.8776 & unpolluted & -0.8553 & unpolluted \\
\hline & & $\mathrm{B}$ & 1.2075 & $\begin{array}{c}\text { Moderate } \\
\text { Polluted }\end{array}$ & -0.9734 & unpolluted & -0.9138 & unpolluted \\
\hline $\mathbf{1 0}$ & $\begin{array}{c}\mathbf{A 2} \\
\mathbf{0}\end{array}$ & $\mathrm{A}$ & 1.6256 & $\begin{array}{c}\text { Moderate } \\
\text { Polluted }\end{array}$ & -0.2359 & unpolluted & 0.1807 & Unpolluted to Moderate \\
\hline & & $\mathrm{B}$ & -0.5227 & unpolluted & -0.3026 & unpolluted & 0.8493 & Unpolluted to Moderate \\
\hline
\end{tabular}
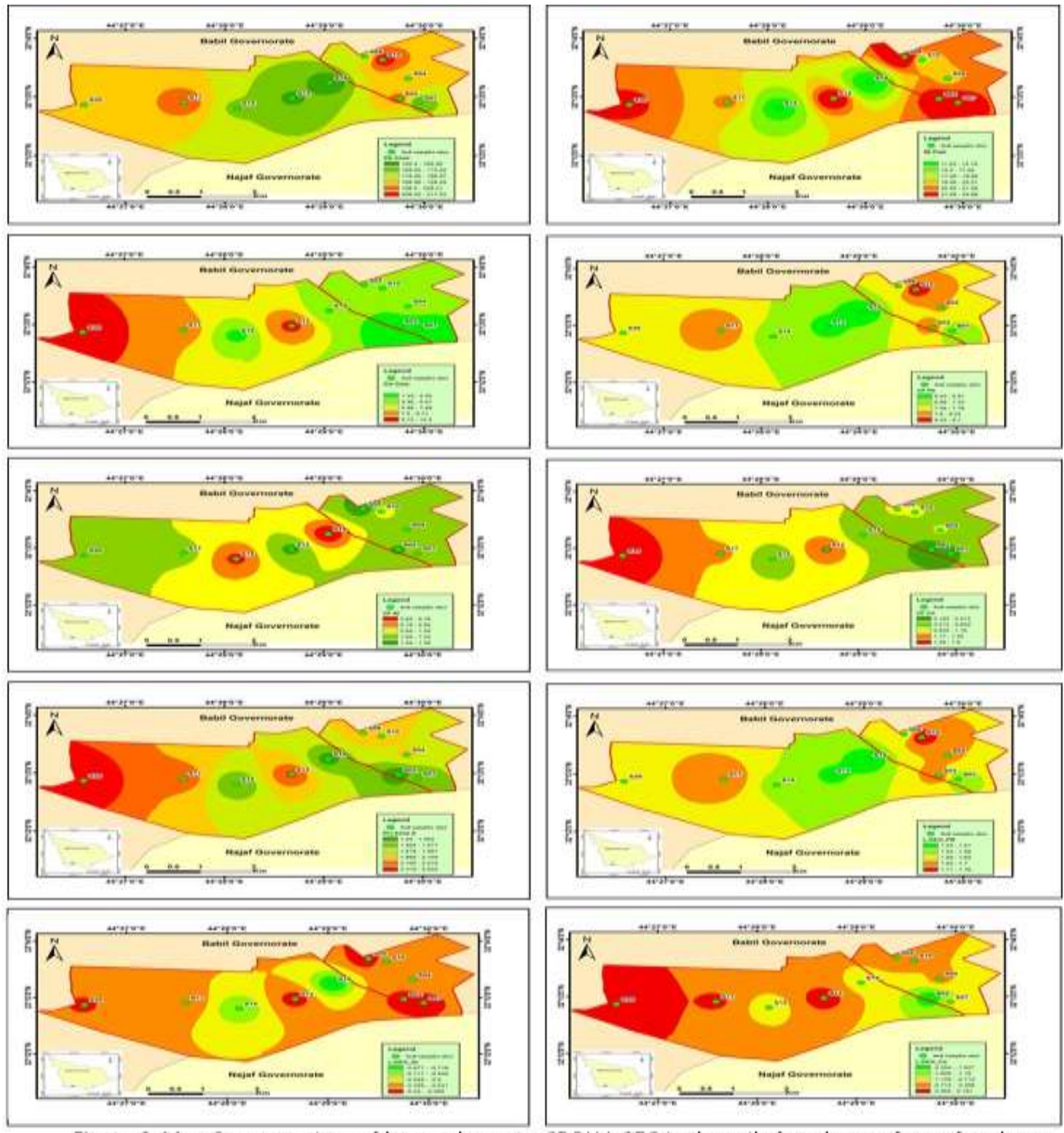

Fieure 6: Map Concentrations of heavy elements, CF,PLI,I-GEO in the soil of study area for surface layer

\section{Conclusions}

The current study showed that the air of the research area contained high concentration of total suspended particles (TSP), especially in the winter Season, which exceeded the global and national determinants. As a result of the continuous industrial processes in the region, with brick factories being probably the main reason, the concentrations of most heavy elements in the air of the region exceeded the limits allowed globally and nationally. The analysis of the cellulose filters revealed that the air of the region contained high concentrations of $\mathrm{Pb}, \mathrm{Ni}$, and $\mathrm{Co}$. The high increase in these elements is due to the industrial processes of the brick, where the fuel used in the combustion process 
contains high concentrations of elements that are transferred into the atmosphere with black smoke out of the chimneys. The volatilization of dust by air movement may lead to increased concentration of elements in the air; It should also be taken into account that the soil of the region is fragmented by industrial processes, especially the movement of vehicles that contribute to enrich the air of the region with some elements, and the exhaust of these compounds may contain different concentrations of elements. We also observed a noteworthy increase in concentrations of both gases of $\mathrm{NO}_{2}$ and $\mathrm{SO}_{2}$, especially in the winter, which is due to the fact that the levels of all the heavy elements, gases and total suspended particles are increased in the air with increasing moisture of the atmosphere. Low temperatures and high humidity work on capturing heavy elements for longer periods in the atmosphere before moving to areas far from the source of pollution or falling and depositing on the soil.

Soil analysis showed that the soil of the region contained high concentrations of trace elements $(\mathrm{Pb}$, $\mathrm{Ni}, \mathrm{Co}$ ). This increase can be attributed to the fall of the precursors of the brick factories on the soil of the region. Clay minerals and soil organic matter could have adsorbed and accumulated these elements to high concentrations, which were then transferred to different layers of the soil. Consequently, these elements might reach the groundwater and surface water, where their presence is not a problem in itself if the concentrations are low, but increasing their concentration and there mobility through the mediums (Air, soil, water, plant) is one of the most important problems to cause environmental pollution. The evidence from contamination indices (CF and I-geo) showed unpolluted to moderate states for all studied elements except lead, which caused a highly polluted rank to the studied area. As for PLI, pollution was observed in all the studied areas inside and outside the brick factories. Generally, the high levels of pollution are due to industrial activities, the absence of vegetation cover surrounding the factories, insufficiently high chimneys, and the use of crude oil in the process of production. Such pollution causes danger to the lives of workers and the population living near the area.

\section{References}

1. Muzaffar, S.A. 2014. Brick factories in the province of Najaf And the impact of waste on the (human, soil, vegetation), Islamic College University Journal , 27: 283-335.

2. Achakzai, K., Khalid, S. and Bibi, A. 2017. Determination of heavy metals in agricultural soil adjacent to functional Brick Kilns: a case study of Rawalpindi. Science Technology and Development, 34(3): 122-129.

3. Al-Farraj, A.S., M.I. Al-Wabel, Al-Shahrani, T.S., El-Maghraby, S.E. 2015. Soil and Plant Contamination with Heavy Metals at Mahad AD Dahab as Affected by the Distance from the Mine Area, King Saud University, Faculty of Food and Agricultural Sciences, Soil Science Department, Agricultural Research Center,143.

4. Skinder, B.M., Sheikh, A.Q., Pandit, A.K. and Ganai, B.A. 2014. Brick kiln emissions and its environmental impact: A review. J. Ecol. Natl.Environ., 6: 1-11.

5. Al- Kawaz, L.S. 2017. Emissions impact of Alkifil Bricks Factory in Conocarpus lancifolius and Dodonaea viscosa Plants, M. Sc. Thesis, University of Babylon., 140p.

6. Buday, T. 1980. Stratigraphy and Paleogeography in Kassab, I. M. and Jassim, S. Z. (eds.).The Regional Geology of Iraq. Vol. 1, Geol. Surv.and Minr. Invest. Baghdad, Iraq, 445p

7. Al- Attiyah, M.J. 2006. An najaf land, Geological Historical and natural resources, $1^{\mathrm{ST}}$ edition, alNabras printing and publishing Est., Arabic book.

8. Hijab, B.R., Al-Dabbas, M. and Al-Haddad, F.M. 1996a. Tectonic history evolution of Iraq. $J$. Geol. Iraq. 31(2): 23 P.

9. Ahirwar, N. K., Gupta, G., Singh, R. and Singh, V. 2018. Assessment of present heavy metals in Industrial affected Soil Area of Mandideep, Madhya Pradesh, India. Int. J. Curr. Microbiol. App. Sci, 7(1): 3572-3582.

10. Soares, H. M., Boaventura, R. A. R. and Esteves, J. da Silva. 1999. Sediments as Monitors of Heavy Metal Contamination in the Ave River Basin (Portugal): Multivariate Analysis of Data, Environmental Pollution, 105: 311-323.

11. Tomlinson, D.L., Wilson, J.G., Harris, C.R. and Jeffney, D.W. 1980. Problems in the assessment of heavy metal levels in estuaries and the formation of a pollution index, Helgol. Wiss. Meeresunters, 33: 566-572. 
12. Gong, Q., Deng, J., Xiang, Y., Wang, Q. and Yang, L. 2008. Calculating pollution indices by heavy metals in ecological geochemistry assessment and a case study in parks of Beijing. J. Chin. Univ. Geosci. 19(3): 230-241.

13. Harikumar, P.S. and Jisha, T.S. 2010. Distribution pattern of trace metal pollutants in the sediments of an urban wetland in the Southwest Coast of India. Int. J. Eng. Sci. Technol. 2 (5):840-850.

14. Singh M., Ansari A.A., Muller G. and Singh I.B. 1997. Heavy metals in freshly deposited sediments of the Gomati River a tributary of the Ganga River: Effects of human activities, Environmental Geology, 29: 246-252.

15. Issa, M. J. and Qanbar, A. S. Assessment of Heavy Metal Contamination in Euphrates River Sediments from Al-Hindiya Barrage to Al-Nasiria City, South Iraq.

16. Boszke, L., Sobczynski, T. and Kowalski, A. 2004. Distribution of Mercury and Other Heavy Metals in Bottom Sediments of the Middle Odra River (Germany/Poland). Polish Journal of Environmental Studies, 13: 495-502.

17. Sinex, S.A. and Helz, G.R.1981. Regional geochemistry of trace elements in Chesapeake Bay sediments. Environ. Geol. 3: 315-323.

18. Buccolieri, A., Buccolieri, G. and Cardellicchio, N. 2006. Heavy metals in marine sediments of Taranto Gulf, Ionian Sea, Southern Italy. Mar. Chem. 99: 227-235.

19. Nagajyoti PC, LeeKD, Sreekanth TVM. 2010. Heavy metals, occurrence and toxicity for plants:a review. Environ Chem Lett, 8(3): 199-216.

20. Mohammed, M. S. and Abdullah, E. J. 2016. Heavy Metals Pollution Assessment of the Soil in the Northern Site of East Baghdad Oil Field, Iraq. Iraqi Journal of Science, 57(1A): 175-183.

21. Hodges, L. 1973. "Environmental pollution Survey emphasizing physical and chemical principles ", New York, Holt Rinehart and Winston.

22. Al- Sultany, A. R., 2006. Pollution of Air \& Soil in Al- Nahrawan Area East Baghdad by Heavy Metals Produced From Brick Factories, Msc. Thesis, University of Baghdad, College of Science, Dept. of Geology, P. 119.

23. Krauskopf, K. B. 1967. Introduction to the Geochemistry, 2nd ed. Tokyo, Mc Grew-Hill, Kogakusa, 617p.

24. Kabata-Pendias, A. and Mukherjee, A.B. 2007. Trace Elements from Soil to Human. SpringerVerlag Berlin Heidelberg. pp: 561.

25. Goldschmidt U. M. 1954. Geochemistry, Oxford, Univ. press, London, 730 p.

26. Aubert H. and Pinta, M. 1977. Trace Elements in Soils, Developments in Soil Science 7, Elsevier Scientific Publishing company, Amesterdam, 395p.

27. Adebowale, K.O, Agunbide, F.O. and Olu-Owolabi, B. 2006. Trace metal concentration, site variations and partitioning pattern in water and bottom sediments from coastal area: A case study of Ondo Coast, Nigeria, Environmental Research Journal, 3(2): 46-59.

28. Adamu, S., Ayuba, M., Murtala, A., \& Uriah, L. A. 2014. Assessment of potentially toxic metals in soil and sediments of the Keana Brinefield in the Middle Benue Trough, North central Nigeria.

29. Kargar, M., Khorasani, N. A., Karami, M., Rafiee, G. H. and Naseh, R. 2012. An investigation on $\mathrm{As}, \mathrm{Cd}, \mathrm{Mo}$ and $\mathrm{Cu}$ contents of soils surrounding the Meyduk Tailings Dam. International Journal of Environmental Research, 6(1): 173-184. 